\title{
Kaasava hariduse rakendamist toetavate hoiakute kujundamine õpetajakoolituse esmaõppes
}

\author{
Katrin Poom-Valickis ${ }^{\text {a1 }}$, Triin Ulla ${ }^{\mathrm{a}}$ \\ ${ }^{a}$ Tallinna Ülikooli haridusteaduste instituut
}

\begin{abstract}
Annotatsioon
Õpetajakoolitusel on kaalukas roll kujundada tulevastes õpetajates positiivne hoiak kaasava hariduse suhtes ning oskused ja teadmised, et toetada erinevate õppijate õppimist. Siinse uuringu eesmärk oli kaardistada üliõpilaste hoiakuid kaasava hariduse rakendamise suhtes enne ja pärast õpetajate kutseõpingute mooduli õppeaine „Õppe diferentseerimine“ läbimist. Lisaks kaardistati kursuse ülesehitusega seotud aspekte, mis toetasid üliõpilaste arvates enim nende arusaamade, oskuste ja hoiakute kujunemist. Eel- ja järelküsitluse tulemuste analüüs näitas, et üliõpilaste hoiakud muutusid kaasava hariduse rakendamise suhtes positiivsemaks ning kasvas usk enda suutlikkusse toetada erinevate õppijate õppimist. Avatud küsimuste vastuste analüüsist selgus, et üliõpilaste tähenduslikku õppimist mõjutas kõige enam õppetöö korraldus, kus teoreetilised teadmised seoti praktilise võimalusega õpitut töös erivajadustega õppijatega rakendada ning kogemust kaasõppijatega reflekteerida.
\end{abstract}

Võtmesõnad: kaasav haridus, õpetajakoolitus, õpetajate hoiakud

\section{Sissejuhatus}

Õpetajate esmaõppe üks ülesandeid on tagada, et õpetajakoolituse lõpetajatel oleksid olemas kutsestandardis sätestatud vajalikud pädevused õpetajatööks kaasavas klassiruumis ning valmisolek neid pädevusi pidevalt arendada. Varasematele uuringutele toetudes teame, et õpilaste edukust mõjutavate tegurite hulgas on õpetaja mõju üks olulisemaid (nt Rivkin, Hanushek \& Kain, 2005) ning eriti määrav on see just erituge vajavate óppurite puhul (Forlin, Cedillo, Romera-Contreras, Fletcher, \& Hernandez, 2010; Timperley \& Alton-Lee, 2008). Õpetajate kvaliteet on aga otseselt seotud õpetajahariduse kvaliteediga

Haridusteaduste instituut, Tallinna Ülikool, Narva mnt 25, 10120 Tallinn; katrinpv@tlu.ee. 
ning nii nagu teistegi haridusmuutuste elluviimisel, on ka kaasava hariduse rakendamisel võtmeroll õpetajal, tema hoiakutel ja pädevustel. Üha mitmekultuurilisem ja heterogeensem õpilaskontingent esitab väljakutseid kõikide riikide haridussüsteemidele ning seetõttu otsitakse üle maailma lahendusi, kuidas arendada õpetajakoolitust nii, et kursused, mida pakutakse, oleksid akadeemiliselt ja praktiliselt asjakohased ning toetaksid kaasava hariduse rakendamist erinevates haridusastmetes. Kuigi kaasava hariduse eesmärk on tugevdada haridussüsteemi võimekust jõuda kõikide õppijate (UNESCO, 2009), mitte ainult erivajadustega õppijateni, ei ole need eesmärgid realiseerunud sellisel määral, nagu oodatud.

Eestis on kaasava hariduse idee levimisest nüüdseks möödunud 15-20 aastat, kuid haridus- ja teadusministeeriumi 2014. aasta analüüsist selgub (HTM, 2015), et „teoreetiliselt omaksvõetud ja dokumentides kinnitatud õpikäsitus, õppijate eri tüüpi andekuste väärtustamine ning erivajaduste märkamine ei ole muutunud õppeprotsessi lahutamatuks osaks" (lk 17). Dokumendis rõhutatakse just varajast märkamist ja probleemidega tegelemise olulisust lasteaias ja algklassides, et ennetada edasist haridustee katkestamist. Arvestades, et paljud üliõpilased lópetavad õpetajakoolituse tundes, et pole tööks erivajadustega õpilastega piisavalt ettevalmistatud (Forlin, Keen, \& Barrett, 2008) ning Eestis kogutud andmetel tunneb 75\% tegevõpetajatest vajadust täienduskoolituse järele hariduslike erivajadustega õpilaste kaasamiseks (Räis, Kallaste, \& Sandre, 2016), on õpetajakoolitusprogrammide arendamine võtmetähtsusega.

Samas tuuakse kaasava hariduse alaseid koolitusprogramme analüüsides välja, et need koosnevad tihti üksikutest, omavahel sidumata suuresti teoreetilistest kursustest, kuigi koolipraktika eeldab nende teooriate rakendamist ja lõimimist (Britzman, 2003). Probleemina nimetatakse ka seda, et õpetajakoolituse esmaõppes pakutakse tulevastele õpetajatele sageli spetsiifilistele erivajadustele keskenduvaid eripedagoogika kursusi, mis Florian ja Rouse (2009) sõnul pigem aitavad tugevdada arusaama, et selliste laste eest vastutavad eelkõige need, kes on saanud sobiva eriväljaõppe. Eri õpetajakoolituse kursused keskenduvad ka kaasava hariduse rakendamist toetavatele tahkudele, nagu ópetaja oskused ja pädevused, positiivsed hoiakud kaasamise suhtes, suurem kontakt erivajadustega inimestega (Forlin \& Chambers, 2011), kuid ei kata kõiki kaasava hariduse rakendamise tahke. Siinkohal on oluline märkida, et peale õpetajate tõhusa ettevalmistamise kaasava lähenemisviisi rakendamiseks hariduses tuleb silmas pidada ka riigi kultuurikonteksti, hariduse ajaloolist ja poliitilist arengut ning haridus- ja koolisüsteemi eripärasid.

Eesti elukestva õppe strateegiast lähtuvad hariduspoliitilised suunad ning Tallinna Ülikooli arengukavast lähtuvad eesmärgid andsid tõuke õpetajakoolituse kutseõpingute mooduli sisu uuendamisele Tallinna Ülikoolis 2016. 
aastal. Varem eraldiseisvad väiksemamahulised ained lõimiti neljaks integreeritud aineks, mis moodustavad ühtse terviku: „Õppimise emotsionaalsed ja sotsiaalsed aspektid“ (6 EAP), „Arengu ja õppimise toetamine“ (6 EAP), „Õppe diferentseerimine“ (6 EAP) ja „Õpetaja ja õpilane õppijatena koolis ja ühiskonnas" (6 EAP). Kogu moodulit läbiv teema on õpetaja professionaalsus ja seda toetav autonoomia. Õpetaja oskused ennast ja oma tööd analüüsida, uurida, teha koostööd ning langetada selle põhjal läbimõeldud otsuseid võimaldavad toime tulla haridusmuutustega ning olla protsesside teadlik suunaja ja mõjutaja nii klassiruumis, koolikeskkonnas kui ka ühiskonnas.

Kuigi aluse õppimise baasprotsesside mõistmiseks loovad esimesel semestril läbitavad ained „Arengu ja õppimise toetamine“ ning „Õppimise emotsionaalsed ja sotsiaalsed aspektid“, käsitletakse kaasava hariduse temaatikat ja kõigi õppijate, sealhulgas hariduslike erivajadustega õppijate õppimise toetamisvõimalusi aines „Õppe diferentseerimine“. Seetõttu keskendume siin artiklis just muudatustele aines „Õppe diferentseerimine“, mille põhieesmärk on kujundada tulevastes õpetajates positiivsed hoiakud ning valmisolek kaasava hariduse rakendamiseks koolikeskkonnas. Nimelt tajusime subjektiivselt teatud muutusi üliõpilaste hoiakutes pärast esimeste oluliste muudatuste sisseviimist ainesse ning selle sidumist praktikaga. Muutused väljendusid meie jaoks eelkõige aine lõputööde esitlustes, kus üliõpilased rõhutasid arusaama, et muutuma peavad nemad õpetajatena, nende hoiakud, lähenemised, mitte ei pea eeldama, et õppija lihtsalt muutub. Rõhutati kannatlikkuse ja õpetaja positiivse usu olulisust õppijasse, sest muutused võtavad aega. Siit tekkis ka huvi selgitada välja üliõpilaste hoiakuid ja nendes toimuvaid muutusi ainekursuse jooksul ning katsetada selleks sobilikke uurimisinstrumente. Hoiakutele keskendusime eelkõige seetõttu, et õpetajate hoiakud ja uskumused mõjutavad otseselt nende käitumist õpilastega (Silverman, 2007) ja on eeltingimuseks tõhusate lähenemisviiside kasutamisel teistest eristuvate õppijate toetamisel (Loreman, Forlin, \& Sharma, 2014), omades seega suurt mõju klassikliimale ja õpitulemustele. Järgnevas alapeatükis anname esmalt ülevaate aine „Õppimise diferentseerimine" arenduspõhimõtetest ja rakendatud muudatustest ning seejärel uuringu fookuses olnud hoiakute ja uskumuste olulisusest kaasava hariduse rakendamisel.

\section{Õpetajakoolituse kursuse „Õppe diferentseerimine“ ülesehituse põhimõtted}

Uue õppeaine loomisel lõimiti TLÜ õpetajate kutseõpingute mooduli arendusprotsessi käigus varasemad kolm eraldiseisvat ainet „Erivajadusega õppija toetamine“, „Ôpetaja kui uurija“ ja „Õpetajakoolituse praktika“ üheks 
õppeaineks, mille eesmärk on kujundada väärtustav hoiak tööks erivajadustega lastega, baasteadmised kaasamispraktikatest ja valmidus õpetamispraktikat kaasava hariduse kontekstis õppija vajadustest lähtuvalt kohandada. Ainete integreerimise üks eesmärke oli teooria ja praktika lõhe ületamine ning üliõpilaste uurimusliku mõtteviisi toetamine. Nimelt on rahvusvahelised uuringud näidanud, et õpetajakoolituse üliõpilastest saavad asjatundlikumad praktikud kaasava hariduse rakendamisel, kui õpe toetab õpetaja kui reflekteeriva praktiku ja uurija kujunemist (Barrett \& Green, 2009).

Uue aine loomisel pöörati tähelepanu sellele, et teoreetilised ja praktilised teadmised oleksid omavahel lõimitud, sest paljud uurijad rõhutavad, et kaasava hariduse kursustel jääb vajaka just praktikast, kus õppijal on võimalus oma uskumusi uurida ja edendada ning seejärel óppida, kuidas toime tulla õppijate mitmekesisusest tulenevate vajadustega reaalses klassiruumis (Jordan, Schwartz, \& McGhie-Richmond, 2009). Seetõttu lõimiti „Õppe diferentseerimise“ ainega ka „Õpetajakoolituse praktika II“ mahuga 3 EAP, mis võimaldas üliõpilastel kursusel õpitut kohe praktikasse rakendada. Praktikaülesanded on seotud ainekursuse teemadega, alustatakse klassi vaatlustega ja seejärel keskendutakse individuaalsele õppijale. Ülesannete sisu on toetada juhendava õpetajaga kokkuleppel kas individuaalse õppija, rühma või klassi õppimist, diferentseerides õpet ja leides tegevusuuringu põhimõtteid rakendades sobivad strateegiad tuge vajavate õppijate õppimise toetamiseks. Ainekursusel pööratakse olulist tähelepanu sobivate sekkumiste valikule (diferentseerimise põhimõtted ja võimalused, sekkumisstrateegiad, VEPA käitumisoskuste mängu metoodilised põhimõtted jne) ning toetatakse samm-sammult tegevusuuringu kava, andmekogumismeetodite ja analüüsi koostamise protsessi. Tegevusuuringu kava koostamisel ja sobivate sekkuvate tegevuste valimisel on toeks aine „Õppe diferentseerimine“ õppejõud ja aines käsitletavad teemad (õpiraskused, aktiivsus- ja tähelepanuhäire, käitumisraskused, autismispektri häired, andekus kui erivajadus, sooline ja kultuuriline eripära).

Planeeritud ja klassiruumis tehtud tegevusi arutatakse kaasõppijatega ning neid tagasisidestab õppejõud. Koos sekkuvate tegevuste rakendamisega hinnatakse koostöös juhendava õpetajaga nende tõhusust, toetudes kogutud andmetele (nt õpilaste tööd, vaatlusmärkmed, tagasiside). Aine lõppeb eksamiga, milleks on artikli vormis esitatav kirjalik juhtumianalüüs, mis seob kokku aines omandatud teadmised ja oskused, läbitöötatud teaduskirjanduse ning praktika käigus rakendatud sekkuvad tegevused konkreetse õppija või õppijate rühma õppimise toetamisel. Oluline koht eksamitöös on refleksioonil, mille käigus analüüsitakse enda kui õpetaja õppimist ja tegevusi tegevusuuringul.

Selle kursuse üks põhieesmärke on kujundada tulevastes õpetajates positiivne hoiak kaasava hariduse suhtes, sest varasemad uuringud on näidanud, 
et kui õpetajal on positiivne hoiak ja usk kõigi õppijate arengupotentsiaali toetamise võimalikkusesse, leiavad ka õpitud teadmised ja oskused suurema tõenäosusega rakendust praktikas teistest eristuvate õppijate toetamisel (Loreman, Forlin, \& Sharma, 2014). Uuringud näitavad ka, et üliõpilaste hoiakuid, teadmisi ja oskusi kaasava hariduse suhtes on võimalik mõjutada just kursuste või õppemoodulite käigus, mis sisaldavad praktikat ja reflekteerivat õpetamist (Symeonidou, 2017), mis suunavad õpetajaid analüüsima isiklikke õpetamise põhimõtteid ning esitama küsimusi oma õpetamise kohta, võimaldavad teha koostööd probleemide lahendamisel ning pakuvad tuge tõenduspõhiste praktikate leidmisel, hindamisel ja rakendamisel (Sharma, 2010). Seetõttu soovisime kaardistada muutusi üliõpilaste hoiakutes kaasava hariduse rakendamise suhtes enne ja pärast uuendatud ainekursuse läbimist, mis toetub eespool nimetatud põhimõtetele.

\section{Kaasava hariduse rakendamist toetavad hoiakud}

Uuringud näitavad, et õpetajate hoiakud on kaasavas klassiruumis olulised edukuse määrajad, sest nad mõjutavad õpetaja käitumist, mis omakorda mõjutab klassikliimat ja õpilaste eduvõimalusi (nt Avramidis \& Norwich, 2002; Jordan et al., 2009; Silverman, 2007). Positiivsed hoiakud ennustavad kõige paremini kaasavat haridust puudutavate reformide edukust (Forlin, 2010), samal ajal kui õpetajate, vanemate ja haridusametnike negatiivsed hoiakud on kõige olulisemad takistused eduka kaasamise rakendamisel (Mittler, 2003). Samuti on leitud, et haridustöötajad, kes suhtuvad kaasamisse positiivselt, rakendavad õppeprotsessis ka enam individuaalsete erinevustega arvestavaid õpetamisstrateegiaid (Campbell, Gilmore, \& Cuskelly, 2003; Forlin, 2010).

Varasematele uuringutele tuginedes võib välja tuua, et õpetajate hoiakuid kaasamisse mõjutab oluliselt nii see, millised on õpetaja varasemad kokkupuuted erivajadustega, kui ka see, kuivõrd mures ollakse enda pädevuste, aga ka keskkonna pakutava toe pärast. Näiteks on leitud, et need ópetajad, kel on olnud varasem kokkupuude hariduslike erivajadustega inimestega ja teadmised nendest, on kaasamise suhtes positiivsemalt hälestatud (Burke \& Sutherland, 2004). Samuti on positiivsem nende õpetajate suhtumine kaasamisse, kes on ressursside kättesaadavuse pärast vähem mures (Lambe \& Bones, 2006). Häidkind ja Oras (2016) leidsid Eestis tehtud uuringus, et lasteaiaõpetajate ja õpetajate hoiakute erinevusi kaasamise suhtes saab samuti valdavalt seletada õppijate, personali ning töökeskkonna erisusega. Selles uuringus jõuti ka järeldusele, et lasteaia personali hoiakud on kaasamise suhtes positiivsemad kui koolis, näiteks klassiõpetajad pidasid erivajadustega õppija toetamist sagedamini tugispetsialistide vastutusalasse kuuluvaks ülesandeks kui eelkooli pedagoogid. 
Kuna mitmes uuringus rõhutatakse, et just õpetajakoolitusprogrammidel on võtmeroll toetavate hoiakute kujundamisel kaasava hariduse rakendamisel (Forlin \& Hopewell, 2006; Andrews, 2002), soovisime põhjaliku uuenduskuuri läbi teinud kursuse „Õppe diferentseerimine“ õppejõudude ja uurijatena teada saada,

1) millised on üliópilaste hoiakud ja valmisolek kaasava hariduse rakendamiseks kursuse alguses;

2) kuidas erinevad üliõpilaste hoiakud enne ja pärast ainekursuse läbimist;

3) millised ainekursuse tajutud aspektid mõjutasid üliõpilaste hinnangul enim nende arusaamade, hoiakute kujunemist kaasava hariduse rakendamisel klassiruumis.

\section{Metoodika}

\section{Valim ja protseduur}

Siinne uurimus korraldati 2018/2019. õppeaastal Tallinna Ülikooli üliõpilaste, tulevaste aineõpetajate hulgas, kes läbivad magistritasemel õpetajakoolitusprogrammi. Aine „Õppe diferentseerimine“ on üks neljast kohustuslikust ainest õpetajate kutseõpingute moodulis, mis toimub magistriõppe esimese õppeaasta kevadsemestril. Uuringus osalesid kõigi aineõpetajate õppekavade esindajad, sealhulgas kutseõpetajad. Kursuse esimesel loengul tehtud eelküsitluses osales kursusele registreerunud 135 üliópilasest 131 üliõpilast, neist naisi 110 ja mehi 21. Järelküsitlusele vastasid kõik kursuse lõpetanud üliõpilased ja neid oli kokku 118, neist naisi 104 ja mehi 14. Ülevaade vastajate vanuselisest jaotusest on toodud tabelis 1 . Uuringus osalemine oli vabatahtlik ning kuna küsitluses osalejate vastuseid esimesel ja teisel vastamiskorral ei ole võimalik indiviidi tasandil siduda, käsitletakse neid kahe sõltumatu valimina ning järeldusi tehakse üliõpilaste rühmiti, mitte indiviiditi. Uuringus osalejaid informeeriti uuringu eesmärkidest ning sellest, et vastamine on anonüümne. Küsitlus tehti elektroonselt Google’i veebiküsitluse võimalusi kasutades. 
Tabel 1. Ülevaade kursuse alguses ja lõpus küsitluses osalenud üliõpilaste vanuselisest jaotusest

\begin{tabular}{|lcccc|}
\hline & \multicolumn{2}{c}{ Kursuse alguses } & \multicolumn{2}{c|}{ Kursuse lõpus } \\
\hline Vanus & N & $\%$ & N & $\%$ \\
\hline 25 ja noorem & 38 & 29 & 33 & 28 \\
\hline $26-35$ & 45 & 34 & 35 & 30 \\
\hline $36-45$ & 29 & 22 & 33 & 28 \\
\hline 46 ja vanem & 19 & 15 & 17 & 14 \\
\hline \multicolumn{1}{c}{ Kokku } & 131 & 100 & 118 & 100 \\
\hline
\end{tabular}

\section{Mõõtevahendid}

Õpetajakoolituse üliõpilaste hoiakute ning kaasava hariduse rakendamiseks valmisoleku väljaselgitamiseks koostati küsimustik, millele kursuse lõpus lisati avatud küsimused, et kaardistada, kuidas mõjutas üliõpilaste arvates kursuse ülesehitus enim nende arusaamade, oskuste ja hoiakute kujunemist.

Selgitamaks välja üliõpilaste kaasava hariduse rakendamiseks valmisolekut, küsiti üliõpilastelt kursuse alguses, kas neil on varasemaid kokkupuuteid erivajadustega inimestega, kogemusi erivajadustega õpilaste õpetamisel ning kuivõrd enesekindlalt nad tunnevad end HEV õpilaste kaasamisel õppetöösse. Taustaküsimuste koostamisel olid aluseks Forlini, Earle'i, Loremani ja Sharma (2011) uuringu taustaküsimused.

Üliõpilaste hoiakute analüüsiks kasutati The Teacher Attitudes Toward Inclusion Scale’i (Cullen, Gregory, \& Noto, 2010) küsimustikku. Küsimustik koosnes kokku 14 väitest, mis jagunesid kolme alaskaalasse. Küsimustiku Eesti oludele sobivaks kohandades jätsime välja viimase küsimuse, mis viitas spetsiifilisele koostöömudelile ning sisu mõttes kordas eelmisi õpetaja ja eripedagoogi koostöö olulisusele viitavaid küsimusi. Väidetele vastamiseks kasutati seitsmepalliskaalat, kus 1 - „ei ole üldse nõus“ ja 7 - „nõustun täielikult“. Nii eel- kui ka järelküsitlusel kontrolliti küsimustiku faktorstruktuuri peakomponentide meetodil tehtud faktoranalüüsiga, kasutades Promaxi pööramist. Nii eel- kui ka järelküsitlusel jaotusid väited kõige paremini kolmefaktorilisse struktuuri sarnaselt originaalhindamisvahendiga, kus esimene puudutas hoiakuid HEV õppijate tavaklassi kaasamise suhtes (nt „Kõigil haridusliku erivajadusega õppijatel peaks olema võimalus õppida võimalikult palju tavaklassis"). Sellesse faktorisse laadus kuus väidet (Cronbachi $\alpha=0,87$ ). Teise faktorisse laadunud neli väidet $(\alpha=0,83)$ puudutasid uskumusi kaasamise tõhususe kohta ning olid sõnastatud negatiivselt, s.o kahtlustena kaasava hariduse rakendamise tõhususe 
kohta (nt „Kahtlen HEV õppijate tavaklassi kaasamise tõhususe osas, sest neil tihti puuduvad toimetulekuks vajalikud akadeemilised oskused“). Kolmas faktor, kuhu kuulus kokku kolm väidet $(\alpha=0,77)$ kirjeldasid eri poolte rolli ja vastutust kaasamise kohta (nt „Vastutus HEV óppijate õppimise toetamisel tavaklassis peaks olema tavaklassi õpetaja ja eripedagoogi vahel jagatud“). Edasiste analüüside aluseks võeti peakomponentide analüüsi käigus saadud skaalade koondskoorid.

Lisaks uuriti õpetajakoolituse üliõpilaste hoiakuid erivajadustega õpilaste tavaklassi kaasamisel. Nimelt pidid üliõpilased eel- ja järelküsitluses hindama, kuivõrd nad on nõus väitega, et järgmisi erivajadustega õppijaid võiks õpetada tavaklassis. Erivajadustest olid välja toodud õpiraskused, käitumisraskused, füüsilised erivajadused, kuulmis,- nägemis- ja kõneraskused, terviseprobleemid, vaimne puue (kognitiivne puue, arenguhäire) ning liitpuue. Küsimused koostati, toetudes Holley (2015) ja haridusliku erivajadusega õpilaste kaasava hariduskorralduse (Räis, Kallaste, \& Sandre, 2016) uuringus toodud küsimustele õpetajate hoiakute kohta erivajadustega õppijate tavaklassi kaasamisel. Väiteid, kas järgneva erivajadusega õppijat võiks õpetada tavaklassis, tuli hinnata neljapalliskaalal, s.o „kindlasti mitte“, „pigem mitte“, „pigem nõus“, „täiesti nõus“.

Tagasiside saamiseks kursuse aspektide kohta paluti kursuse lópus üliõpilastel vastata avatud küsimustele. Küsimused koostasid uuringu korraldajad ning olid sõnastatud järgnevalt: „Palun too kursuse jooksul õpitust (loenguteemad, tekstid, ülesanded) välja kolm olulisemat teadmist, mis kõige enam toetasid sinu arusaamist erivajadustega õppijate kaasamisest! Põhjenda soovi korral lühidalt oma hinnangut!“; „Palun nimeta kolm aspekti, mis kursusel õpitust (loenguteemad, tekstid, ülesanded) mõjutas kõige enam sinu oskusi erivajadustega õppijate kaasamiseks! Põhjenda soovi korral lühidalt oma hinnangut!“ ning „Palun nimeta kolm aspekti, mis kursusel õpitust (loenguteemad, tekstid, ülesanded) mõjutas kõige enam sinu hoiakuid erivajadustega õppijate kaasamise suhtes! Põhjenda soovi korral lühidalt oma hinnangut!“‘

\section{Andmeanaliüis}

Arvandmete analüüsiks kasutati statistikapaketti SPSS 25. Kõigepealt kontrolliti uuringu eel- ja järelküsitluses Eesti oludele kohandatud The Teacher Attitudes Toward Inclusion Scale'i (Cullen, Gregory ja Noto, 2010) skaalade faktorilist struktuuri. Faktorite sisemist reliaablust kontrolliti Cronbachi $\alpha$ abil. Kuna eel- ja järelküsitluses osalenud üliõpilaste andmeid ei olnud võimalik personaliseerida, mis on ka uuringu suurimaid piiranguid, siis võrreldi omavahel kahe erineva sõltumatu rühma vastuseid. Rühma 1 moodustasid üliõpilased, 
kes vastasid küsimustele kursuse alguses, ja rühma 2 üliõpilased, kes täitsid küsimustiku pärast kursuse läbimist. Kuna vastused ei olnud normaaljaotusega, kasutati kahe sõltumatu rühma vastuste erinevuste statistilise olulisuse hindamiseks andmeanalüüsil mitteparameetrilist Mann-Whitney testi.

Üliõpilaste avatud vastuste analüüsil kasutati temaatilist analüüsi (Braun \& Clarke, 2006). Analüüsi aluseks olid 118 üliõpilase vastused, kokku 756 lausungit ehk keskmiselt 6,4 lausungit tudengi kohta. Analüüsiühikuks võeti lausung ehk lause või lõik, mis väljendas mõttelist tervikut. Olgugi et vastajatel paluti välja tuua õppesisu külgi, mis toetasid eri pädevuse tahkude (teadmised, oskused, hoiakud) toetamist, näitas andmete esmane vaatlus, et vastused olid suurel määral märksõnalised (nt elulised näited, refleksioon, VEPA metoodika) ja kattusid sageli mitmes avatud küsimuses. Sellest tulenevalt otsustati liita iga vastaja kolm vastust avatud küsimustele üheks ning kodeerida ühe tudengi vastuste tervikkogum.

Kasutades materjali korduvat lugemist ja avatud kodeerimist, kodeeriti esimeses kodeerimisringis lausungid sisulise sarnasuse alusel 31 teemakategooriasse. Näiteks andekus, autismipedagoogika, teemade defineerimine, refleksioon, lugemisülesanded. Teise kodeerimisringi eesmärk oli teemakategooriate koondamine, kasutades selleks muster- ehk metakategooriatesse kodeerimist (pattern coding). Muster- ehk metakategooriate moodustamise eesmärk on koondada suurem hulk kodeeritud alateemasid optimaalsemasse tähenduslikku analüüsiühikusse või metakoodi (Saldana, 2009). Analüüsiprotsessi tulemusel moodustus kõikidest teemadest neli metakategooriat (vt tabel 5). Esimesse kategooriasse „Õppe ülesehitus“ kuulusid tudengite poolt esile toodud õppe ülesehituse või korralduse aspektid, mis toetasid arusaamist, oskusi või hoiakute muutusi, teise kategooriasse „Teemad ja tööriistad" koondusid loengutel või seminaridel käsitletud konkreetsed teemad, teadmised ja praktikad. Kolmandasse metakategooriasse „Vaatenurgad ja tõlgendusviisid“ paigutati vastused, mis esindasid kaasava haridusega seotud üldisemaid vaatenurki, hoiakuid või põhimõtteid, ning neljandasse kategooriasse muud vastused (näiteks kriitilised hoiakud kaasava hariduse suhtes, mõju puudumine või paralleelsest õpetajakoolituse ainest välja toodud õppesisu).

Esmase analüüsi tegi artikli üks autoritest. Seejärel jagati analüüsimaterjali teise uurijaga ning arutati esmased koodid läbi ning sõnastati vajaduse korral need ümber. Usaldusväärsuse tagamiseks toimusid põhjalikud arutelud, et uurijad jõuaksid konsensuseni. 


\section{Tulemused}

\section{Üliõpilaste valmisolek ja hoiakud kaasava hariduse rakendamiseks enne ja pärast ainekursuse läbimist}

Kursuse alguses tehtud eelküsitluses osalenud üliõpilastest $(\mathrm{n}=131) 73 \%-1$ oli varasem kokkupuude erivajadustega inimestega ning vaid $27 \%$ sõnul neil varasem kokkupuude puudus. Samuti selgus, et 131 eelküsitluses osalenud üliõpilasest 30,5\%-1 $(n=40)$ puudub varasem kogemus erivajadustega õppijate õpetamisel, vähest kogemust tunnistas $51,1 \%(n=67)$ ja suurt kogemust 18,3\% $(\mathrm{n}=24)$ üliõpilastest. Eelküsitluse analüüsitulemused näitasid, et üliõpilased, kellel oli varasem kokkupuude erivajadustega inimestega, hindasid kursuse alguses kõrgemalt ka enda valmisolekut HEV õppijaid õppetöösse kaasata $(\mathrm{n}=95)$ võrreldes üliõpilastega, kellel eelnev kokkupuude puudus $(\mathrm{n}=36)$, $\mathrm{z}(131)=-2,991, \mathrm{p}<0,05$.

Analüüsides Mann-Whitney testi abil kursuse eel- ja järelküsitluses osalenud üliõpilaste hinnangute erinevust enda enesekindlusele HEV õpilaste kaasamisel õppetöösse, selgus, et üliõpilaste enesekindlus oli kursuse lõpus oluliselt suurem $(U=5987,50, z=-3,42, p<0,01)$ kui kursuse alguses. Ülevaate üliõpilaste vastuste jaotusest eel- ja järelküsitlusel küsimusele „Minu enesekindlus HEV õpilaste kaasamiseks õppetöösse" annab tabel 2. Kursuse käigus vähenes eelkõige nende üliõpilaste arv, kes hindasid enda toimetulekut HEV õppijate kaasamisel madalaks või väga madalaks, ning suurenes nende tudengite arv, kes hindasid enda toimetulekut keskmiseks või kõrgeks.

Tabel 2. Üliõpilaste enesekindlus HEV õpilaste kaasamisel õppetöösse

\begin{tabular}{lcccc} 
Enesekindlus HEV õppijate & \multicolumn{2}{c}{ Kursuse alguses } & \multicolumn{2}{c}{ Kursuse lõpus } \\
kaasamiseks õppetöösse & $\mathrm{N}$ & $\%$ & $\mathrm{~N}$ & $\%$ \\
\hline Väga madal & 12 & 9,2 & 1 & 0,8 \\
\hline Madal & 38 & 29,0 & 22 & 18,6 \\
\hline Keskmine & 67 & 51,1 & 73 & 61,9 \\
\hline Kõrge & 9 & 6,9 & 20 & 16,9 \\
Väga kõrge & 5 & 3,8 & 2 & 1,7 \\
Kokku & 131 & 100 & 118 & 100 \\
\hline
\end{tabular}


Analüüsides üliõpilaste valmisolekut kaasata erinevate erivajadustega õppijaid tavaklassi, ilmnesid kursuse alguses ja lõpus tehtud küsitluse tulemustes samuti positiivsed erinevused. Üliõpilastel paluti hinnata kursuse alguses ja lõpus, kuivõrd nad on valmis kaasama järgnevate erivajadustega õpilasi tavaklassi või peaksid need õpilased õppima pigem eriklassis või erikoolis. Võrreldes kursuse algusega, suurenes kursuse lõpus üliõpilaste valmisolek kaasata erivajadustega õppijaid tavaklassi. Nimelt näitas Mann-Whitney test, et kursuse lõpus ( $\mathrm{n}=118$ ) oldi oluliselt enam valmis kaasama tavaklassi õpiraskustega õpilasi $(\mathrm{U}=5417,50, \mathrm{z}=-4,50, \mathrm{p}<0,01)$ kui kursuse alguses $(\mathrm{n}=131)$. Kursuse lõpus hindasid üliõpilased enda valmisolekut kaasata tavaklassi käitumisraskustega $(\mathrm{U}=6115,00, \mathrm{z}=-3,12, \mathrm{p}<0,05)$, kuulmisraskustega $(\mathrm{U}=6209,00$, $\mathrm{z}=-2,96, \mathrm{p}<0,05)$, nägemisraskustega $(\mathrm{U}=6721,00, \mathrm{z}=-1,94, \mathrm{p}<0,05) \mathrm{ja}$ kõneraskustega õpilasi $\mathrm{U}=6420,00, \mathrm{z}=-2,58, \mathrm{p}<0,05)$ oluliselt kõrgemalt kui kursuse alguses. Vaimse ja liitpuudega õppijate puhul jäädi pigem seisukohale, et need õppijad võiks õppida erikoolis või tavakooli eriklassis. Samas füüsiliste erivajaduste ja terviseprobleemidega õppijate suhtes arvati läbivalt, et sellised õpilased võiks õppida pigem tavaklassis. Tabel 3 annab ülevaate üliõpilaste vastuste jaotusest kursuse alguses ja lõpus.

Tabel 3. Üliõpilaste eel- ja järelküsitluse vastuste jaotustabel

\begin{tabular}{llcc} 
& & \multicolumn{2}{c}{ Vastuste $\%$} \\
\cline { 3 - 4 } & & Kursuse alguses & Kursuse lõpus \\
\hline Õpiraskustega õppija & Kindlasti mitte & 1,5 & 0,8 \\
& Pigem mitte & 29,8 & 9,3 \\
& Pigem nõus & 52,7 & 55,9 \\
& Täiesti nõus & 16,0 & 33,9 \\
Käitumisraskustega & Kindlasti mitte & 6,9 & 5,1 \\
óppija tavaklassis & Pigem mitte & 47,3 & 28,8 \\
& Pigem nõus & 39,7 & 55,1 \\
& Täiesti nõus & 6,1 & 11,0 \\
Füüsiliste erivajadustega & Kindlasti mitte & 2,3 & - \\
\cline { 2 - 3 } ôppija tavaklassis & Pigem mitte & 13,7 & 11,9 \\
& Pigem nõus & 43,5 & 45,8 \\
& Täiesti nõus & 40,5 & 42,4
\end{tabular}




\begin{tabular}{|c|c|c|c|}
\hline & & \multicolumn{2}{|c|}{ Vastuste $\%$} \\
\hline & & Kursuse alguses & Kursuse lõpus \\
\hline \multirow{4}{*}{$\begin{array}{l}\text { Kuulmisraskustega õppija } \\
\text { tavaklassis }\end{array}$} & Kindlasti mitte & 6,1 & 1,7 \\
\hline & Pigem mitte & 31,3 & 16,9 \\
\hline & Pigem nõus & 48,1 & 61,9 \\
\hline & Täiesti nõus & 14,5 & 19,5 \\
\hline \multirow{4}{*}{$\begin{array}{l}\text { Nägemisraskustega } \\
\text { óppija tavaklassis }\end{array}$} & Kindlasti mitte & 7,6 & 1,7 \\
\hline & Pigem mitte & 30,5 & 24,6 \\
\hline & Pigem nõus & 47,3 & 56,8 \\
\hline & Täiesti nõus & 14,5 & 16,9 \\
\hline \multirow{4}{*}{$\begin{array}{l}\text { Kõneraskustega õppija } \\
\text { tavaklassis }\end{array}$} & Kindlasti mitte & 4,6 & 1,7 \\
\hline & Pigem mitte & 26,7 & 16,9 \\
\hline & Pigem nõus & 55,0 & 59,3 \\
\hline & Täiesti nõus & 13,7 & 22,0 \\
\hline \multirow{4}{*}{$\begin{array}{l}\text { Terviseprobleemidega } \\
\text { õppija tavaklassis }\end{array}$} & Kindlasti mitte & 1,5 & - \\
\hline & Pigem mitte & 19,1 & 15,3 \\
\hline & Pigem nõus & 49,6 & 54,2 \\
\hline & Täiesti nõus & 29,8 & 30,5 \\
\hline \multirow{4}{*}{$\begin{array}{l}\text { Vaimse puudega õppija } \\
\text { tavaklassis }\end{array}$} & Kindlasti mitte & 22,1 & 18,6 \\
\hline & Pigem mitte & 59,5 & 59,3 \\
\hline & Pigem nõus & 15,3 & 20,3 \\
\hline & Täiesti nõus & 3,1 & 1,7 \\
\hline \multirow{4}{*}{$\begin{array}{l}\text { Liitpuudega õppija } \\
\text { tavaklassis }\end{array}$} & Kindlasti mitte & 25,2 & 16,9 \\
\hline & Pigem mitte & 50,4 & 59,3 \\
\hline & Pigem nõus & 20,6 & 22,0 \\
\hline & Täiesti nõus & 3,8 & 1,7 \\
\hline
\end{tabular}

Tulevaste õpetajate hoiakuid kaasava hariduse suhtes hinnati The Teacher Attitudes Toward Inclusion Scale'i küsimustiku abil, kus iga väidet tuli hinnata seitsmepalliskaalal. Küsimustiku väited koondusid kolme peafaktorisse: (1) hoiakud HEV õppijate tavaklassi kaasamise suhtes, (2) uskumused kaasamise tõhususe kohta, (3) uskumused eri poolte rolli kohta. Statistiliselt 
olulised erinevused eelküsitluse $(\mathrm{n}=131)$ ja järelküsitluse $(\mathrm{n}=118)$ vastuste vahel esinesid esimese $(\mathrm{U}=5997,00, \mathrm{z}=-3,06, \mathrm{p}<0,05)$ ja teise faktori puhul $(\mathrm{U}=6556,50, \mathrm{z}=-2,07, \mathrm{p}<0,05)$. Seejuures rühma keskmiste järjekorranumbrite (Mean Rank) põhjal (vt tabel 4) ilmnes, et üliõpilaste hoiakud HEV õppijate tavaklassi kaasamise suhtes olid kursuse lõpus positiivsemad kui alguses. Sama tendents ilmnes ka teise faktori ehk kaasamise tõhususe puhul. Nimelt olid üliõpilaste kahtlused HEV õppijate tavaklassi kaasamise tõhususes kursuse lõpus madalamad kui kursuse alguses.

Tabel 4. Üliõpilaste hoiakute eel- ja järelküsitluse keskmised järjekorranumbrid

\begin{tabular}{llcc} 
& Testi tegemise aeg & N & $\begin{array}{l}\text { Keskmine järjekorra- } \\
\text { number (Mean Rank) }\end{array}$ \\
\hline $\begin{array}{l}\text { Positiivsed hoiakud } \\
\text { HEV õppijate tavaklassi } \\
\text { kaasamisel }\end{array}$ & kursuse alguses & 131 & 111,78 \\
$\begin{array}{l}\text { Kahtlused HEV õppijate } \\
\text { tavaklassi kaasamise } \\
\text { tõhususes }\end{array}$ & kursuse lõpus & 118 & 139,68 \\
$\begin{array}{l}\text { Valmidus koostööks eri } \\
\text { pooltega }\end{array}$ & kursuse lõpus & 118 & 133,95 \\
& kursuse alguses & 131 & 115,06 \\
\hline
\end{tabular}

Statistiliselt olulist erinevust hinnangutes ei ilmnenud kolmandas alaskaalas tavaklassis õpetava õpetaja ja eripedagoogi koostöö aspekte peeti oluliseks nii eel- kui ka järelküsitluses.

Kokkuvõttes võib öelda, et kursuse alguses hindasid üliõpilased enda enesekindlust HEV õppijate kaasamiseks tavaklassi madalamalt kui kursuse lõpus. Kursuse alguses hindasid enda enesekindlust kõrgemalt need üliõpilased, kellel oli varasem kokkupuude hariduslike erivajadustega. Võrreldes kursuse algusega suurenes kursuse lõpus üliõpilaste valmisolek kaasata tavaklassi erineva erivajadusega õppijaid. Samuti olid hoiakud HEV õppijate tavaklassi kaasamise ja kaasamise tõhususe suhtes kursuse lõpus oluliselt positiivsemad kui kursuse alguses.

Järgnevalt analüüsime üliõpilaste vastuseid küsimusele, millised õppeprotsessi tegurid nende arusaamu ja hoiakuid kursuse jooksul mõjutasid. 


\section{Kursuse aspektid, mis mõjutasid üliõpilaste hinnangul kaasava hariduse rakendamisest arusaamise kujunemist}

Kvalitatiivse andmeanalüüsi tulemusel liigitati üliõpilaste vastused avatud küsimustele nelja metakategooriasse, mille sisu kirjeldus koos väidete kvantitatiivse jaotusega on esitatud tabelis 5 .

Tabel 5. Üliõpilaste avatud vastuste kategooriad

\begin{tabular}{|c|c|c|c|}
\hline $\begin{array}{l}\text { Vastuste } \\
\text { meta- } \\
\text { kategooria }\end{array}$ & Selgitus & $\begin{array}{c}\text { Lausungite } \\
\text { kvantitatiivne } \\
\text { jaotus, } n=756\end{array}$ & $\begin{array}{c}\text { Lausungite } \% \\
\text { koguarvust }\end{array}$ \\
\hline $\begin{array}{l}\text { Õppe } \\
\text { ülesehitus }\end{array}$ & $\begin{array}{l}\text { Tegevusuuringuga seotud } \\
\text { tegevused, refleksioon ja koge- } \\
\text { muste vahetus seminaril, praktiliste } \\
\text { lugude ja eluliste näidete jagamine, } \\
\text { ülesanded seminaridel või iseseisva } \\
\text { tööna, haarav või inspireeriv hoiak, } \\
\text { millega õppejõud teadmisi jagasid. }\end{array}$ & 135 & $18 \%$ \\
\hline $\begin{array}{l}\text { Teemad ja } \\
\text { tööriistad }\end{array}$ & $\begin{array}{l}\text { Autismipedagoogika, käitumis- } \\
\text { või õpiraskuste toetamine, } \\
\text { andekus, VEPA käitumisoskuste } \\
\text { mängu metoodika põhimõtted ja } \\
\text { tööriistad ja muud spetsiifilised } \\
\text { teadmised või toetusstrateegiad. }\end{array}$ & 264 & $35 \%$ \\
\hline $\begin{array}{l}\text { Vaatenurgad } \\
\text { ja tõlgendus- } \\
\text { viisid }\end{array}$ & $\begin{array}{l}\text { Seisukohad valmisoleku või } \\
\text { vajaduse kohta õpilasi kaasata, } \\
\text { õpet diferentseerida, erinevusi } \\
\text { märgata, kõiki õpilasi toetada. } \\
\text { Uued arusaamad kaasava hariduse } \\
\text { olemusest. }\end{array}$ & 307 & $41 \%$ \\
\hline Muu & $\begin{array}{l}\text { Mõju puudus või oli negatiivne, } \\
\text { vastus puudus, toodi välja teise } \\
\text { aine käigus käsitletud teemad või } \\
\text { teadmised. }\end{array}$ & 50 & $7 \%$ \\
\hline
\end{tabular}


Oluline on välja tuua, et suurima osa (41\%) kodeeritud lausungitest moodustavad positiivsed ja laiemat kaasamisreaalsust peegeldavad hoiakud, vaid 13 tudengit 118-st (11\%) tõi ka välja, et nende hoiakud kaasava hariduse suhtes kursuse vältel ei muutunud. Viimastest viis märkis, et hoiak oli juba enne kursuse läbimist positiivne, ning neli, et hoiak on jätkuvalt kriitiline, neli jättis hoiaku olemuse täpsustamata.

Olgugi et avatud küsimustega paluti üliõpilastel viidata õppe ülesehituse tahkudele (loenguteemad, tekstid, ülesanded), mis nende arusaamist, oskusi ja hoiakuid mõjutasid, sõnastati vastustes väga sageli kursuse aspektide asemel hoiakulisi lausungeid. Järgnevalt on välja toodud tudengite seisukohtade jaotus iga kategooria kaupa, jaotusi illustreerivad iseloomulikud väljavõtted tudengite vastustest, mis on esitatud kursiivis.

Õppe ülesehituse osad, mis arusaamade, oskuste ja hoiakute kujunemist mõjutasid

$18 \%$ lausungite koguarvust moodustasid viisid, kuidas ainet õpetati. Olgugi et tudengitele esitatud küsimuses viidati spetsiifilisemalt teemadele, tekstidele ja ülesannetele, toodi tihti välja ka kursuse üldist korraldust ja õppejõudude aine edastamise laadi.

48\% kõigist sellesse kategooriasse liigitatud lausungitest $(n=65)$ tõi esile kursuse üldist ülesehitust: seotust praktikaga, tegevusuuringu teostamist, kogemuse ja eluliste näidete jagamist ja ühist kogemuse refleksiooni seminaridel; sealjuures mainis ligikaudu kolmandik (28\%) kõigist küsitletud tudengitest, et nende kompetentsus kasvas just tegevusuuringu kaudu, mis toetas oskust probleemi märgata ja võimalikke lahendusi leida:

Tegevusuuring esitas väljakutse ja tekitas huvi lisatuge vajava ópilasega töötamiseks.

Refleksioon - iseenda tegevuse reflekteerimise olulisus ja kasulikkus. Tegevusuuringu koostamine ning seeläbi oskus ópilaste vajadusi paremini märgata ning oskus kohandada ennast õpetajana ópilaste parimate saavutuste nimel.

Kolmandik (30\%) kategooria vastustest osutas aine kohustuslikele lugemistekstidele, mille seas kõige populaarsematena kaasava hariduskorralduse uuring (Räis et al., 2016) koos valdkonna seadustikuga ja C. Rogersi „Taasleitud käitumine“. Üle viiendiku siin kodeeritud vastustest (22\%) tähistas viisi, kuidas teadmised olid esitatud, mis näitas, et ainesisu kõrval mängib olulist rolli ka selle edastamise laad: 
Eriliselt tahan välja tuua autismi käsitlevat loengut, kust saime väga palju väärtuslikku siseinfot autistlike joontega suhestumise kohta (taaskord nii lähenemisviise ja nippe, aga ka sügavamat arusaama autismispektril olevate inimeste mõttemaailmast). Kiidan väga lektorit!

Eks kõige enam mõjutavad õppejõud ja nende hoiakud ;) Samuti hoiakute põhjendatus. Meeldib, kui materjale tõendab statistika, mida meile palju presenteeriti.

\section{Kursusel omandatud teadmised ja tööriistad}

Teemade ja tööriistade kategoorias toodi küll kasulikuna esile pea kõiki kursusel käsitletud teemasid ja viise erivajadusega õppija kaasamiseks, sealjuures nii käitumis- kui ka õpiraskustega toimetulekuks. Kõige enam nimetati autismispektri ja andekuse teemaga seotud teadmisi ja sekkumisviise (vastavalt $13 \%$ ja $17 \%$ kategooria vastustest) ning VEPA käitumisoskuste mängu metoodika võimalusi õpilaste toetamiseks kaasavas klassiruumis (25\% kõikidest kategooria vastustest ehk 65 lausungit):

VEPA metoodika kasutamine - aitab kaasa eneseregulatsioonile, prosotsiaalse käitumise toetamisele, tekitab emotsionaalselt turvalise keskkonna, mis on ópiprotsessis väga oluliseks faktoriks. Kunagi õpetajaks saades tahaksin ka ise seda meetodit katsetada ja proovida.

Mitmed andekuse ja autismipedagoogika teemaga seotud lausungid paigutusid ka järgmisena esitletud metakategooria alla, sest tõid esile hoopis märkamise ja õpilaste toetamise suhtes olulisi hoiakuid.

\section{Hoiakud kaasava hariduse suhtes}

Olgugi et tudengitel paluti nimetada kursuse eri aspekte, mis mõjutasid nende arusaamu, oskusi ja hoiakuid, nimetati enamasti just hoiakuid või kaasava hariduse mõtteviisi kandvaid lausungeid. Kuna nimetatud metakategooria alla kodeeritud lausungite hulk oli teiste metakategooriatega võrreldes suurim, on nende teemakategooriate (sh kvantitatiivne) jaotus koos kategooria selgitusega välja toodud tabelis 6 . 
Tabel 6. Kategooria „Vaatenurgad, tõlgendusviisid“ teemakategooriate jaotus

\begin{tabular}{|c|c|c|c|}
\hline $\begin{array}{l}\text { Vastuse } \\
\text { teemakategooria }\end{array}$ & Kategooria selgitus & $\begin{array}{c}\text { Lausungite } \\
\text { kvantitatiivne } \\
\text { jaotus, } \mathrm{n}=307\end{array}$ & $\begin{array}{c}\text { Lausungite \% } \\
\text { koguarvust }\end{array}$ \\
\hline $\begin{array}{l}\text { Võimaluste } \\
\text { märkamine ja } \\
\text { neile } \\
\text { keskendumine }\end{array}$ & $\begin{array}{l}\text { Võimaluste nägemine õpilaste } \\
\text { tugevuste märkamiseks, nende } \\
\text { arengu toetamiseks, koostööks } \\
\text { kolleegidega. Kasutegurid eri- } \\
\text { vajadusega õppijatele ja nende } \\
\text { kaaslastele. Kasutegurid ühis- } \\
\text { kondlikus plaanis. }\end{array}$ & 130 & $43 \%$ \\
\hline $\begin{array}{l}\text { Õpetaja omaduste } \\
\text { rõhutamine: } \\
\text { kõigi märkamine, } \\
\text { toetamine, } \\
\text { järjekindlus }\end{array}$ & $\begin{array}{l}\text { Vastused sellest, mis on õpetaja } \\
\text { omadused ja strateegiad, mis } \\
\text { kaasamist toetavad, kuidas ja miks } \\
\text { märgata ja toetada kõiki õpilasi ning } \\
\text { olla selles järjekindel. }\end{array}$ & 87 & $28 \%$ \\
\hline $\begin{array}{l}\text { Õppe } \\
\text { diferentseerimise } \\
\text { olulisus ja } \\
\text { võimalused }\end{array}$ & $\begin{array}{l}\text { Hoiakud, mis tõid esile, miks on } \\
\text { oluline õpet diferentseerida ja } \\
\text { millistest printsiipidest sellest } \\
\text { lähtuda saaks. }\end{array}$ & 52 & $17 \%$ \\
\hline $\begin{array}{l}\text { Eesti kaasava } \\
\text { haridusreaalsuse } \\
\text { mõtestamine }\end{array}$ & $\begin{array}{l}\text { Kaasava hariduse defineerimine } \\
\text { ja haridusreaalsuse mõtestamine, } \\
\text { erivajadusega õppijate tähenduse ja } \\
\text { osakaalu üle arutlemine. }\end{array}$ & 38 & $12 \%$ \\
\hline
\end{tabular}

Metakategooria kõige sagedasemini esitatud lausungid olid seotud võimaluste märkamise ja esiletoomisega kaasavas hariduses (43\% kõigist metakategooriasse kodeeritud vastustest):

Haridus on kõigi põhiõigus ja kaasamisel on oluline keskenduda just toetamisele, mitte analüüsile, et miks ei sobi. Mõtteviisi muutus õppijatevaheliste erinevuste mõistmisel on oluline, sest kõigil peab olema parim võimalus õppimiseks ja arenemiseks.

See, et inimesed ongi erinevad, aga erivajadust ei tohi karta, vaid tuleb selgeks teha millega tegu, et sa oskaksid aidata, toetata, olla olemas. Tuleb teha koostööd kolleegidega, lapsevanematega, et last óppimisel toetata, mitte proovida üksi hakkama saada, mitu pead on ikka parem kui üks. Sa ei ole oma murega üksi - keegi kindlasti oskab sind aidata, sulle häid ideid pakkuda, sind toetada. Murele ei pruugi kohe lahendus tulla, ära anna alla, proovi midagi muud.

Vastustes peegeldus arusaam, et eelkõige peab muutuma õpetaja ning leidma keskkonna kohandamiseks võimalusi: 
Mõte, et esmalt mõtleme sellele, mida me saame teha, mitte sellele, mida me ei saa. Leiame lahendusi, mitte vabandusi.

Keskenduma peab sellele, kuidas keskkond õppimist toetab, mitte sellele, miks keegi keskkonda ei sobi.

Tihti toodi esile kaasava hariduse kasutegurit ühiskondlikus plaanis:

Kaasamine on oluline nii erivajadustega lastele endale - sotsiaalsed oskused ja kuuluvustunne - kui ka „tavalastele“, kuna ühiskonnas on palju erivajadusega inimesi, kellega tuleb osata teha koostööd, mitte neid vältida (kool annab eeskuju).

Kui HEV õpilased on kaasatud tavaklassidesse, siis tavalapsed ei hakka neid kuidagi ühiskonnast eristama ning HEV muutub „nähtamatuks“.

Samuti rõhutati õpetaja hoiakulisi aspekte, üldisi omadusi ja oskusi erinevate õpilaste toetamisel (28\% kategooria lausungitest):

Teiseks on erivajadus ka tugev võimekus, mis ületab ülejäänud klassi keskmise taseme, ja ka seda tuleks õppida märkama.

Kõikide lastega saab leida ühist keelt, tuleb ainult osata näha ja teada, kuidas saaks kõige paremini aidata.

17\% metakategooria lausungitest peegeldasid hoiakuid õppe diferentseerimise kohta. Siin kajastusid hoiakud märkamise ja kaasamise olulisusest, tähelepanekud, kuidas õpet diferentseerida, sealhulgas rakendada universaalselt kujundatud õppe printsiipe, ning seisukohad selle kohta, miks kaasamine on laiemas perspektiivis tähtis:

Õppe diferentseerimise võimalused - disainida õpe nii, et HEV laps oleks ree peal ning ka ülejäänud klass võidaks (erinevatel viisidel küsimuste esitamine jms).

On palju erinevaid võimalusi ja meetodeid, kuidas ümber kujundada klassiruum ja õppimine nii, et see oleks sobilik kõigile.

$12 \%$ metakategooria lausungitest olid üldiselt neutraalselt sõnastatud seisukohad, mis mõtestasid kaasava hariduse olemust:

Sain teada, millised on haridussüsteemi võimalused HEV õpilastega tegutsemisel.

Erivajadusega õppija saab viibida tavaklassis õppides tuleviku mõttes loomulikus keskkonnas. 
Vabavastuste kokkuvõttes võib öelda, et kursus on mõjutanud üliõpilaste hoiakuid ja enesekindlust positiivselt. Õppe ülesehituse tahkudest rõhutati enim kursusedisainis loodud võimalusi omandatud teadmisi praktikas rakendada ja kogemust kaasõppijatega reflekteerida. Samuti joonistus välja aine edastamisviisi olulisus ehk õppejõudude eeskuju teadmiste ja kogemuste jagamisel, mis üliõpilaste õppimist mõjutas. Aine raames käsitletud teemad ja praktilised strateegiad olid õppijate jaoks tähenduslikud ning peegeldusid üliõpilaste vastustes avatud küsimustele.

Olgugi et üliõpilastel paluti tuua välja kursuse eri aspekte, mis nende arusaamade, teadmiste ja hoiakute kujunemist erivajadustega õppijate kaasamise suhtes toetasid, tõid tudengid vastustes läbivalt enim välja mõtteviise ja hoiakuid, mis on kaasava hariduse rakendamisel olulised. Seega võib vabavastuste analüüsi põhjal öelda, et ilmselt on kursuse kõige suurem mõju olnud üliõpilaste hoiakutele. Vastanud üliõpilased tõid kaasavat haridust puudutavate hoiakute kategooria alla paigutunud vastuste seas enim esile kaasavas hariduskorralduses peituvaid võimalusi ja nende olulisust ning rõhutasid õpetajate vastutust kõigi õppijate toetamisel. Olgugi et vastuste seas esines kaasava hariduse aadressil ka skeptilisi ja negatiivseid hoiakuid, on viimaste hoiakute osakaal tudengite vastuste seas väga väike. Vaid neli tudengit 118st kirjutas, et nende hoiak on kaasava hariduse suhtes endiselt kriitiline.

\section{Arutelu}

Siinse uurimuse eesmärk oli selgitada välja õpetajakoolituse üliõpilaste hoiakuid kaasavasse haridusse enne ja pärast õpetajakoolituse kursuse „Õppe diferentseerimine" läbimist. Õppejõudude ja uurijatena soovisime teada, kuivõrd need hoiakud kursuse vältel muutusid ning milliseid aspekte toovad üliõpilased enim esile õppimise juures kursuse puhul, kus teooria on praktikaga tihedalt seotud, mis sisaldab uurimuslikku lähenemist ning kus õpetavad erineva praktilise kogemusega õppejõud. Selleks, et selgitada välja üliõpilaste hinnangul nende hoiakuid enim mõjutanud kursuse aspektid, paluti kursuse lõpus üliõpilastel vastata kolmele avatud küsimusele. Kvalitatiivselt kogutud andmed aitasid mõista, millised kursuse aspektid võivad olla kvantitatiivselt täheldatud muutuste taga.

Nii nagu õpetajakoolituse tudengite taust, s.o varasem töö ja elukogemus, on väga erinevad, nii erinevad õpingute alguses ka üliõpilaste hoiakud ja valmisolek kaasava hariduse rakendamiseks ning erinevate erivajadustega õppijate tavaklassi kaasamiseks. Kursuse alguses hindas pool üliõpilastest (51\%), et nende enesekindlus HEV õppijate kaasamiseks tavaklassi on keskmine, 38\% 
üliõpilastest arvas, et see on madal või väga madal ning vaid $11 \%$ hindas seda kõrgeks või väga kõrgeks. Kursuse alguses olid HEV õppijate tavaklassi kaasamise suhtes enesekindlamad need üliõpilased, kellel oli varasem kokkupuude erivajadustega inimestega. Seega võib öelda, et eelnevad isiklikud kokkupuuted erivajadustega inimestega on seotud positiivsemate hoiakutega kaasavasse haridusse. Sarnased tulemused on saadud ka varasemates uuringutes ehk on leitud, et õpetajad, kel on olnud eelnev kokkupuude hariduslike erivajadustega inimestega ja teadmised nendest, on häälestatud kaasamisse positiivsemalt (Burke \& Sutherland, 2004). Ilmselt vähendab varasem isiklik kokkupuude ühelt poolt hirme, mis on tihti erivajadustega seotud, ning loob suurema valmisoleku n-ö erilisuse normaliseerimiseks.

Selleks, et kujundada õpetajakoolituse üliõpilastel kaasava hariduse suhtes positiivsed hoiakud ning enesekindlus tulla toime praktilistes õppesituatsioonides, on Loremani ja tema kolleegide (2007) sõnul oluline luua üliõpilastele võimalusi otseseks suhtlemiseks erivajadustega õppijatega. See, et praktiline tegevus HEV õppijatega on üliõpilastele oluline, peegeldus ka kursuse lõpus antud vabavastustes. Nimelt rõhutati õppe ülesehituse tahkudest enim kursusedisainis loodud võimalusi omandatud teadmisi praktikas rakendada ja kogemust kaasõppijatega reflekteerida.

Võrreldes eel- ja järelküsitluses osalenud üliõpilasrühmade vastuseid, võib öelda, et kursuse lõpus hindasid üliõpilased enda enesekindlust ning valmisolekut kaasava hariduse rakendamiseks kõrgemalt kui kursuse alguses. Nimelt vähenes kursuse käigus eelkõige nende üliõpilaste arv, kes hindasid oma toimetulekut HEV õppijate kaasamisel madalaks või väga madalaks, ning suurenes nende tudengite arv, kes hindasid oma toimetulekut keskmiselt või kõrgelt. Võrreldes eel- ja järelküsitluses osalenud üliõpilasrühmade vastuseid, võib öelda, et üliõpilaste enesekindlus ning valmisolek erivajadustega õppijaid tavaklassi kaasata oli kõrgem kursuse lõpus. Märksa enam oldi kursuse lõpus valmis kaasama tavaklassi käitumis-, kuulmis-, nägemis- ja kõneraskustega õpilasi. Vaimse ja liitpuudega õppijate puhul jäädi ka kursuse lõpus seisukohale, et need õppijad võiks pigem õppida erikoolis või tavakooli eriklassis. Samas arvati füüsiliste erivajaduste ja terviseprobleemidega õppijate puhul nii kursuse alguses kui ka lõpus läbivalt, et sellised õpilased võiksid õppida pigem tavaklassis.

Tulemused on sarnased varasemate uuringute omadega (Avramidis \& Norwich, 2002), kus on leitud, et õpetajad on enam valmis kaasama tavaklassi kerge erivajadusega õpilasi ning füüsiliste erivajadustega õpilasi, samal ajal kui komplekssete erivajaduste ja käitumisraskustega õpilaste kaasamise suhtes ollakse negatiivsemad. Samas rõhutatakse koolituste positiivset mõju õpetajate hoiakutele ehk paremad oskused ja teadmised loovad ka suurema valmisoleku 
erinevate õppijate kaasamiseks tavaklassi. Nimelt on leitud, et õpetajad, kes on saanud koolitust, muretsevad vähem sellepärast, et erivajadustega õppijate kaasamine tavaklassi tekitab probleeme õpilaste aktsepteerimisega või langetab üldist akadeemilist taset (Sokal, Sharma, 2014). Tulevaste õpetajate hoiakuid kaasava hariduse suhtes hinnati The Teacher Attitudes Inclusion Scale'i küsimustiku abil ning ka siin ilmnesid positiivsed muutused kahes alaskaalas. Nimelt olid üliõpilaste hoiakud HEV õppijate tavaklassi kaasamise ja kaasamise tõhususe suhtes kursuse lõpus märgatavalt positiivsemad kui kursuse alguses.

Olgugi et uuringu ülesehitus ei võimalda kindlalt väita, et muutus on toimunud aines „Õppe diferentseerimine“ osalemise mõjul, võimaldavad avatud küsimustele antud vastuste analüüsi tulemused osutada, et kursus on üliõpilaste hoiakuid ja enesekindlust positiivselt mõjutanud. Seda väites toetume asjaolule, et suurim osakaal (41\%) tudengite lausungitest selle kohta, millised aine aspektid enim nende teadmiste, oskuste ja hoiakute kujunemist mõjutasid, väljendasid just erinevaid hoiakulisi mõttekäike, nii selle kohta, mis on kaasava hariduskorralduse võimalused, kui ka selle kohta, kuidas õpet saab diferentseerida ja milliste hoiakutega peaks õpetaja ise olema või mis strateegiaid kasutama, et erinevaid ópilasi maksimaalselt toetada. See kinnitab uuringu eel kogetud ja artiklis eespool kirjeldatud subjektiivset kogemust, et õppijad kogevad ja väljendavad kursuse lõpus hoiakulist muutust. Kuigi siinse uuringu ülesehitus ei võimalda otsesõnu väita, et kursusel osalemine on täiel määral üliõpilaste hoiakulise muutuse taga, võib siiski öelda, et ainekursuse uuendamine on positiivne samm soovitud muutuse poole, et esmaõpe toetaks positiivseid hoiakuid ja valmisolekut kaasava hariduse rakendamiseks, mis on ka varasemate uuringute põhjal oluline eeldus omandatud teadmiste tõhusaks rakendamiseks (Campbell, Gilmore, \& Cuskelly, 2003; Forlin, 2010).

Kindlasti tuleks tulevikus läbi mõelda, kuidas andmeid koguda nii, et need võimaldaksid veelgi täpsemalt esile tuua, kuidas aine korraldus õpilaste hoiakuid mõjutas. Siinse uuringudisaini kitsendus oli asjaolu, et eri avatud küsimustele antud vastused olid kohati väga sarnased ega võimaldanud sisuliselt eristada, mis mõjutas õppijate teadmisi, oskusi ja hoiakuid, ning kõiki üliõpilaste vastuseid tuli analüüsida koos.

Teoreetiliste teadmiste integreerimist praktilise ja reflekteeriva õppevormiga võib siinse uurimuse põhjal pidada kaasava hariduse hoiakute tõhustamisel sobivaks õppe ülesehituseks. $28 \%$ kursuse lõpetanud tudengitest tõi vabavastustes välja, et tegevusuuring võimaldas neil oma teadmisi, oskusi või hoiakuid kaasava hariduse suhtes tõhustada. Tuge vajava õppija tundmaõppimiseks aega võttes, uurimuslikku mõtteviisi kasutades saame toetada tulevaste õpetajate oskusi ja pädevusi kaasava hariduse rakendamiseks ning kujundada arusaama, et ei ole olemas ühte ja ainuõiget lähenemist, mis sobiks 
kõikidele õppijatele. Ka John Hattie (2012) toob õpilaste toetamise efektiivsete võtete reastamisel esile, et kõige paremini toetab akadeemilisi tulemusi individuaalne lähenemine. Õpetajate teadmised loovad baasi teadlikuks ja eesmärgipäraseks tegevuseks klassiruumis. Tudengite vabavastuste puhul paistis silma ka tendents, et kursuse teemadest nimetati väga palju erinevaid (sh praktilisi) tööriistu, mis õppijate valmisolekut kaasava hariduse rakendamiseks toetasid. Üliõpilaste vastuste üldkogumis said esile toodud ja nimetatud pea kõik kursusel läbitud teemad ja õpilaste toetamise strateegiad, mis lubab järeldada, et viis, kuidas kursus on temaatiliselt üles ehitatud, toetab teadmiste ja arusaamise kujunemist. Küll aga on oluline, et suurel määral tõsteti esile ka andekate laste märkamise ja toetamise teema tähtsust, mis viitab õppijate valmisolekule märgata ja toetada väga erinevaid õppijaid.

Teisalt tuleb silmas pidada, et kuigi õpetajate hoiakud, teadmised ja oskused kaasava hariduse rakendamiseks klassiruumis on olulised ning neid on võimalik õpetajakoolituse käigus kujundada ja tõhustada, sõltub kaasava hariduse rakendamise edukus koolist ja haridussüsteemist tervikuna. Õpetajakoolitus üksi ei suuda leevendada või lahendada kõiki koolide murekohti kaasava hariduse rakendamisel. Kõigi õppijate õppimise ja arengu toetamisel on olulised kõigi õpetajate positiivsed hoiakud ja koostöö, samuti tugispetsialistide olemasolu. Kaasava mõtteviisi juurutamisel organisatsiooni tasandil ning keskkonna loomisel, kus kõigi õppijate, sealhulgas õpetajate õppimine on väärtustatud ja toetatud, on tähtis roll koolijuhil. Nimelt on leitud, et erinevused koolide kaasamise tasemes sõltuvad pigem juhtimise kvaliteedist kui rahastamisest ning just jagatud väärtused, tõekspidamised, hoiakud, traditsioonid ning käitumisnormid, mida kogu koolipere jagab, aitavad kaasavat haridust rakendada. (Mitchell, 2016). Selleks, et koolid suudaksid täita oma ülesannet ja pakkuda kõigile lastele võrdseid haridusvõimalusi, tuleb ühelt poolt pöörata tähelepanu õpetajate hoiakutele ja pädevustele, kuid teisalt peab kogu süsteem toetama lähenemise rakendamist nii eesmärkide, süsteemselt planeeritud tegevuste kui ka ressursside jagamisel. Ülikoolidel on siinkohal oluline roll tõenduspõhiste koolituste pakkumisel nii õpetajatele, koolijuhtidele kui ka tugispetsialistidele, et toetada haridusasutuste püüdlusi kõigi õppijate õppimise toetamisel.

Kuigi siinse uuringu esmased tulemused viitavad, et liigume aine „Õppe diferentseerimine“ arendamisel õiges suunas, tuleb saadud tulemusi käsitleda reservatsioonidega, sest küsitlusele vastas kursuse alguses enam üliõpilasi kui kursuse lõpus ning kasutatud andmekogumisviis ei võimaldanud siduda andmeid indiviidi tasandil. Edaspidi oleks oluline lisaks küsitlusele kasutada erinevaid kvalitatiivseid uurimisvahendeid, et täpsemalt mõista muutuste suunda ja sisu ning neid enim mõjutanud tegureid just indiviidi tasandil. 
Samuti oleks tarvis analüüsida koolikeskkonna mõju tulevaste õpetajate hoiakutele kaasava hariduse rakendamisel ning nende muutusele praktikas pikema aja vältel. Mida paremini oleme teadlikud õpetajate hoiakutest ning neid mõjutavatest teguritest, seda paremini oskame disainida koolitusi, mis toetavad nii õpetajaks õppijate kui ka tegevõpetajate valmisolekut kaasava hariduse rakendamiseks.

\section{Kasutatud kirjandus}

Andrews, L. (2002). Preparing general education pre-service teachers for inclusion: Web-enhanced case-based instruction. Journal of Special Education Technology, 17, 27-35. https://doi.org/10.1177/016264340201700302

Avramidis, E., \& Norwich, B. (2002). Teachers' attitudes towards integration/ inclusion: A review of literature. European Journal of Special Needs Education, 17(2), 129-147. https://doi.org/10.1080/08856250210129056

Barrett, D. \& Green, K. (2009). Pedagogical content knowledge as a foundation for an inter-disciplinary graduate program. Science Educator, 18(1), 17-28.

Braun, V., \& Clarke, V. (2006). Using thematic analysis in psychology. Qualitative Research in Psychology, 3(2), 77-101. https://doi.org/10.1191/1478088706qp063oa

Britzman, D. P. (2003). Practice makes practice. New York: State University of New York Press.

Burke, K., \& Sutherland, C. (2004). Attitudes toward inclusion: Knowledge vs. experience. Education, 125(2), 163-172.

Campbell, J., Gilmore, L., \& Cuskelly, M. (2003). Changing student teachers' attitudes towards disability and inclusion. Journal of Intellectual and Developmental Disability, 28(4), 369-379. https://doi.org/10.1080/13668250310001616407

Cullen, J. P., Gregory, J. L., \& Noto, L. A. (2010). The teacher attitudes toward inclusion scale (TATIS) (technical report ED509930).

Eesti elukestva õppe strateegia 2020. Haridus- ja Teadusministeerium, Eesti Koostöö Kogu, Eesti Haridusfoorum.

https://www.hm.ee/sites/default/files/strateegia2020.pdf

Florian, L. \& Rouse, M. (2009). The inclusive practice project in Scotland: Teacher education for inclusive education. Teaching and Teacher Education, 25(4), 594601. https://doi.org/10.1016/j.tate.2009.02.003

Forlin, C., \& Chambers, D. (2011). Teacher Preparation for Inclusive Education: Increasing Knowledge but Raising Concerns. Asia-Pacific Journal of Teacher Education, 39(1), 17-32. https://doi.org/10.1080/1359866X.2010.540850

Forlin, C., Earle, C., Loreman, T., \& Sharma, U. (2011). The Sentiments, Attitudes, and Concerns about Inclusive Education Revised (SACIE-R) Scale for Measuring Pre-Service Teachers' Perceptions about Inclusion. Exceptionality Education International, 21, 50-65. https://doi.org/10.1037/t69317-000

Forlin, C. (2010). Re-framing teacher education for inclusion. Kogumikus C. Forlin (Toim), Teacher education for inclusion: Changing paradigms and innovative approaches (lk 3-10). Abingdon: Routledge. 
Forlin, C., Cedillo, I., Romera-Contreras, S., Fletcher, T., \& Hernandez, H. (2010). Inclusion in Mexico: Ensuring supportive attitudes by newly graduated teachers. International Journal of Inclusive Education, 14(7), 723-739. https://doi.org/10.1080/13603111003778569

Forlin, C., \& Hopewell, T. (2006). Inclusion - the heart of the matter: Trainee teachers' perceptions of a parent's journey. British Journal of Special Education, 33(2), 55-61. https://doi.org/10.1111/j.1467-8578.2006.00415.x

Forlin, C., Keen, M., \& Barrett, E. (2008). The concerns of mainstream teachers: Coping with inclusivity in an Australian context. International Journal of Disability, Development and Education, 55(3), 251-264. https://doi.org/10.1080/10349120802268396

HTM (2015). Haridus- ja Teadusministeeriumi aasta-analüüs. Tartu: HTM. Vaadatud 02.08.19, https://www.hm.ee/sites/default/files/aastaanalyys2015_0.pdf.

Hattie, J. A. C. (2012). Visible learning for teachers: Maximizing impact on achievement. Oxford: Routledge.

Häidkind, P., \& Oras, K. (2016). Kaasava hariduse mõiste ning õpetaja ees seisvad ülesanded lasteaedades ja esimeses kooliastmes. Eesti Haridusteaduste Ajakiri, 4(2), 60-88. https://doi.org/10.12697/eha.2016.4.2.04

Jordan, A., Schwartz, E., \& McGhie-Richmond, D. (2009). Preparing teachers for inclusive classrooms. Teaching and Teacher Education, 25(4), 535-542. https://doi.org/10.1016/j.tate.2009.02.010

Lambe, J., \& Bones, R. (2006). Student teachers' perceptions about inclusive classroom teaching in Northern Ireland prior to teaching practice experience. European Journal of Special Needs Education, 21(2), 167-186. https://doi.org/10.1080/08856250600600828

Loreman, T., Forlin, C., \&Sharma, U. (2014). Measuring Indicators of Inclusive Education: A Systematic Review of the Literature. Measuring Inclusive Education (International Perspectives on Inclusive Education, 3, 165-187. https://doi.org/10.1108/S1479-363620140000003024

Mitchell, D. (2016). Kaasavad haridusstrateegiad kaasava hariduse juhtriigis UusMeremaal. Eesti Haridusteaduste Ajakiri, 4(2), 2016, 8-18. https://doi.org/10.12697/eha.2016.4.2.02

Mittler, P. (2003). Building bridges between special and mainstream services. Inclusion: theory and practice. http//www.eenet.Org.uk/theory [Vaadatud 02.08.19].

Rivkin, S., Hanushek, E., \& Kain, J. (2005). Teachers, schools, and academic achievement. Econometrica, 73(2), 417-458. https://doi.org/10.1111/j.1468-0262.2005.00584.x

Räis, M.- L., Kallaste, E., \& Sandre, S.-L. (2016). Haridusliku erivajadusega ópilaste kaasava hariduskorralduse ja sellega seotud meetmete tõhusus. Uuringu lóppraport. Saldana, J. (2009). The Coding Manual for Qualitative Researchers. SAGE Publishing. Sharma, U. (2010). Using Reflective Practices for the Preparation of Pre-Service Teachers for Inclusive Schools. Kogumikus C. Forlin (toim) Teacher Education for Inclusion, (lk 102-111). London: Routledge.

Silverman, J. (2007). Epistemological beliefs and attitudes toward inclusion in preservice teachers. Teacher Education and Special Education, 30(1), 42-51. https://doi.org/10.1177/088840640703000105 
Sokal, L., \& Sharma, U. (2014). Canadian In-service Teachers' Concerns, Efficacy, and Attitudes about Inclusive Teaching. Exceptionality Education International, 23(1), 59-71.

Symeonidou, S. (2017). Initial teacher education for inclusion: a review of the literature, Disability \& Society, 32(3), 401-422.

https://doi.org/10.1080/09687599.2017.1298992

Timperley, H., \& Alton-Lee, A. (2008). Reframing teacher professional learning: An alternative policy approach to strengthen valued outcomes for diverse learners. Review of Research in Education, 32, 328-329.

https://doi.org/10.3102/0091732X07308968

UNESCO (2009). Policy Guidelines on Inclusion in Education. Paris: UNESCO. Vaadatud 01.07.19,

https://unesdoc.unesco.org/ark:/48223/pf0000177849/PDF/177849eng.pdf.multi. 


\title{
Supporting positive attitudes towards the implementation of inclusive education in initial teacher education
}

\author{
Katrin Poom-Valickis ${ }^{\text {a1 }}$, Triin Ulla ${ }^{\mathrm{a}}$ \\ ${ }^{a}$ School of Educational Sciences, Tallinn University
}

\begin{abstract}
Summary
It is the aim of inclusive education that equal opportunities of learning and development should be provided for all learners, not just those with special educational needs (UNESCO, 2009). In Estonia, inclusive education has been considered a part of local policies for a few decades, but for many learners it has yet to become an everyday practice (HTM, 2015, p. 50).

Research has shown the teachers' role to be critical in influencing efficient learning (e.g. Rivkin, Hanushek \& Kain, 2005) especially for students who need additional support (Forlin, Cedillo, Romera-Contreras, Fletcher \& Hernandez, 2010; Timperley \& Alton-Lee, 2008). Quality teaching is directly related to the quality of teacher training. As in implementing any educational change, teachers, their attitudes and competences play a key role. The student body is becoming more heterogenous and multicultural throughout the world. Overall solutions must be sought to develop quality teacher training to provide academic and practical relevance, as well as support the implementation of inclusive education at different educational levels.

In 2016, initial teacher training in Tallinn University was reformed, uniting three previously separate courses into a single 6 ECTS "Differentiation of learning" course, with the aim of forming supportive attitudes towards working with children with special educational needs, fostering knowledge of inclusive practices, as well as a willingness to modify the learning environment according to diverse learners' needs. The course was designed to integrate theoretical and practical knowledge, as well as to offer pre-service teachers an opportunity to put their knowledge into practice through action research, carried out in conjunction with teaching practice module II and in cooperation with the supervising teacher. The practical task entailed differentiating between learning for a single student, a group or the whole class. At the end of the course students
\end{abstract}

School of Educational Sciences, Tallinn University, Narva mnt 25, Tallinn 10120 Estonia; katrinpv@tlu.ee 
would submit a graded exam paper, an evidence-based case study about their experience.

As the course was designed to support the development of readiness and positive attitudes towards inclusion, the aim of the current paper was firstly to map the attitudes of pre-service teachers towards inclusive education before and after the course. The relevant aspects of the course that helped shape those attitudes were also studied.

The online survey was carried out during the 2018/2019 school year among the first year Master's level subject teachers participating in the course "Differentiation of learning". Participants filled out the Teacher Attitudes Toward Inclusion Scale (Cullen, Gregory \& Noto, 2010), described their feelings about including SEN-students in lessons and their previous experience with people with special needs; offered their case by case opinion about including specific SEN-students in the general classroom; as well as pointed out aspects from the course (topics, texts, tasks) that helped them gain understanding and improve their skills, and what effect it had on their attitudes towards inclusive education.

Pre-service teachers' self-reported confidence in including SEN-students in lessons was statistically significantly higher at the end of the course. Students with previous contacts with special educational needs reported a significantly higher confidence towards inclusive practices at the end of the course, as compared to the beginning. At the end of the course, pre-service teachers expressed a significantly higher willingness to include special needs students with learning, behavioural, hearing, seeing and speech difficulties in the ordinary classroom. Also, teachers' attitudes towards inclusion were reported to be more positive towards inclusion and inclusion efficacy beliefs subscales, all in all reporting a clear trend of more positive attitudes towards inclusive education and its effectiveness.

Students' open-ended evaluations of the course aspects (topics, texts, tasks) that improved their knowledge, skills and attitudes regarding inclusive education where handled qualitatively, using thematic coding, and divided into descriptive categories based on their similarity, which were later combined into four main meta-categories using pattern coding (Saldana, 2009): 1) aspects of the course design; 2) knowledge and tools gained from the course; 3 ) general supportive ways of thinking about inclusive education and its practice; and 4) any other statements. Although students were asked to point out concrete aspects of the course, the category that mostly appeared among students' answers was the third: making supportive statements about the possibilities and benefits of inclusion. This helps to shed light on the motives behind the trend towards positive attitudes observed in quantitative data. The students 
were very vocal in their opinions on different means of support, potential and the possibilities provided by inclusive education and the role of teacher pedagogic qualities. One third of all students questioned mentioned that a learning design with the possibility to support students through action research and analyse its impact, helped them improve their skills of noticing, supporting, self-reflection, as well as influenced their attitudes about the effectiveness of inclusive education.

Our studies show that pre-service teachers' attitudes, knowledge and skills in implementing inclusive education are subject to positive change through teacher training. However, more emphasis should be directed to the conditions of inclusion at the systemic level of education, for as teacher qualities significantly impact, these alone will not suffice for successful inclusive education policies.

Keywords: inclusive education, initial teacher education, teacher attitudes 